\title{
Absorptive capacity and performance: The role of customer relationship and technological capabilities in high-tech SMEs
}

\section{Tzokas, N}

http://hdl.handle.net/10026.1/10395

10.1016/j.indmarman.2015.02.033

Industrial Marketing Management

All content in PEARL is protected by copyright law. Author manuscripts are made available in accordance with publisher policies. Please cite only the published version using the details provided on the item record or document. In the absence of an open licence (e.g. Creative Commons), permissions for further reuse of content should be sought from the publisher or author. 


\title{
Absorptive capacity and performance: The role of customer relationship and technological capabilities in high-tech SMEs
}

\author{
Nikolaos Tzokas ${ }^{\mathrm{a}, *}$, Young Ah. Kim ${ }^{\mathrm{b}}$, Hammad Akbar ${ }^{\mathrm{c}}$, Haya Al-Dajani ${ }^{\mathrm{d}}$ \\ a Faculty of Business, Plymouth University, Drake Circus, Plymouth, Devon, PL4 8AA, UK \\ b Essex Business School, University of Essex, Southend-on-Sea SS1 1LW, UK \\ c University of Liverpool Management School, University of Liverpool, Liverpool L69 7ZH, UK \\ d Norwich Business School, University of East Anglia, Norwich Research Park, Norwich NR4 7TJ, UK
}

\author{
Embargoed until 31/5/2018
}

\section{A R T I C L E I N F O}

\section{Article history:}

Received 13 February 2013

Received in revised form 24 January 2015

Accepted 2 February 2015

Available online $\mathrm{xxxx}$

\section{Keywords:}

Absorptive capacity

Technological capability

Customer relationship capability

High tech

SMEs

\begin{abstract}
A B S T R A C T
This study focuses on how the interplay between a firm's absorptive capacity (ACAP), and its technological and customer relationship capability contributes to its overall performance. Using structural equation modeling in a sample of 158 firms (316 questionnaires, two respondents per firm) from South Korea's semiconductor industry, we find that a firm's ACAP leads to better performance in terms of new product development, market performance and profitability when used in combination with the firm's capability to engage state of the art technologies in its new product development program (NPD) (technological capability) as well as cultivate strong customer relationships to gain customer insight in NPD (customer relationship capability). By highlighting the interactive nature of absorptive capacity's antecedents and how these relate to firms' performance, this study contributes to the understanding of the role of ACAP as a mechanism for translating external knowledge into tangible benefits in high-tech SMEs, thus leading to important theoretical and practical implications.
\end{abstract}

(c) 2015 Elsevier Inc. All rights reserved.

\section{Introduction}

In today's knowledge-intensive business environment, it is imperative for firms to acquire and use external knowledge to advance innovation and enhance performance (Abecassis Moedas \& Mahmoud Jouini, 2008; Lane, Salk, \& Lyles, 2001). Easy to say, hard to put into practice. The journey from the acquisition of knowledge to its productive use is not easy and many firms struggle (Hull \& Covin, 2010; McGrath, 2001), especially those working in high-technology industries (Rothaermel \& Deeds, 2004; Smith, Collins, \& Clark, 2005). To address this, firms need to develop their absorptive capacity (ACAP) (Cohen \& Levinthal, 1989, 1990), a notion that is increasingly being recognized as a source of competitive advantage (Jansen, Van den Bosch, \& Volberda, 2005; Tu, Vonderembse, Ragu Nathan, \& Sharkey, 2006; Zahra \& George, 2002). ACAP is the firm's ability to utilize externally held knowledge through three processes of exploratory learning, transformative learning and exploitative learning (Lane, Koka, \& Pathak, 2006).

Realizing that firms vary in the successful utilization of knowledge (Cassiman \& Veugelers, 2006; Escribano, Fosfuri, \& Tribó, 2009), scholars have urged for more research to elucidate the character, antecedents/determinants and outcomes of ACAP (Lane et al., 2006;

\footnotetext{
* Corresponding author. Tel.: + 441752585600.

E-mail addresses: nikolaos.tzokas@plymouth.ac.uk (N. Tzokas), yakim@essex.ac.uk (Y.A. Kim), hammad@liv.ac.uk (H. Akbar), h.dajani@uea.ac.uk (H. Al-Dajani).
}

Todorova \& Durisin, 2007; Zahra \& George, 2002). Recent calls have directed attention to integrated approaches whereby ACAP is perceived not in a vacuum but within the wider context of a firm's effort to develop and commercialize innovations (for example, Cepeda Carrion, Cegarra Navarro, \& Jimenez Jimenez, 2012; Fernhaber \& Patel, 2012; Kostopoulos, Papalexandris, Papachroni, \& Ioannou, 2010; Vega Jurado, Gutiérrez Gracia, \& Fernández de Lucio, 2008; Volberda, Foss, \& Lyles, 2010; Zhou \& Wu, 2010). Embracing such an integrated approach and drawing lessons from a marketing management perspective, the recipe for competitive success in the development and commercialization of new products is best reflected, among other things, in a balanced attention to the technological and customer related aspects emerging in the innovation or new product development (NPD) process (Baker \& Sinkula, 1999; Cooper \& Kleinschmidt, 1995; Morgan, Vorhies, \& Mason, 2009). To achieve this, firms invest heavily in acquiring, among other things, two seemingly distinct but inextricably linked capabilities: first, technological capability (TC) which allows firms to perform technical functions, such as R\&D through the use of state of the art technologies thus producing technologically superior products (Teece, Pisano, \& Shuen, 1997). Secondly, customer relationship management capability (CRC) which, allows firms to create strong customer relationships enabling customer insight and customer focus in the new product development activity (Day, 2002).

Thus, it may seem reasonable to assume that innovation performance is associated with organizational contexts where there is synergy amongst the ACAP of the firm and its TC and CRC. Or in practical terms, it 
is logical to assume that the more a firm has a clear ability to produce technologically superior products (TC) while capitalizing on a deep understanding of its customer base (CRC), the higher will be its capacity to explore, integrate and exploit (ACAP) external knowledge, and by implication the better its product, market and financial performance will be.

However, to the best of our knowledge, the relationship between a firm's technological and customer relationship capabilities and ACAP, and their synergistic effect upon performance, is yet to be tested empirically. Studies which link capabilities with ACAP have focused on IT capabilities (Liu, Ke, Wei, \& Hua, 2013), knowledge creation capabilities (Su, Ahlstrom, Li, \& Cheng, 2013), or political networking capabilities (Kotabe, Jiang, \& Murray, 2014). Zhou and Wu (2010) show that while TC fosters exploitation, high level of such capability impedes explorative innovation, whereas Afuah (2002) suggests a positive relationship between TC and exploration. Thus, we still lack an understanding of the relationship between TC and ACAP, and indeed CRC and ACAP where we also struggled to find a study. In the absence of a systematic, empirical testing of these relationships, we cannot be confident about how TC and CRC affect ACAP and synergistically contribute to organizational performance. This gap needs to be addressed because a firm's technological and customer relationship capabilities are becoming crucial to produce new products and services in order to respond to the dynamic market needs (see Handfield \& Bechtel, 2002; Hsieh \& Tsai, 2007).

The other end of the successful application of ACAP is organizational performance (Escribano et al., 2009). Given that ACAP is a resource consuming process, to provide further credence to the role it plays in extracting value from a firm's resources (Camisón \& Forés, 2010; Escribano et al., 2009), more evidence is needed on ACAP's relationship with a firm's performance (Kostopoulos et al., 2010), especially in the context of high-technology industries. Our paper addresses this level by researching these issues in a sample of SMEs from the South Korean semiconductor industry.

The following section provides the theoretical background and relevant literature support for our hypotheses. After that we explain the research methods employed to address these hypotheses and we conclude with a discussion of the study's results and associated theoretical and managerial implications.

\section{Theoretical background and hypotheses}

\subsection{Absorptive capacity}

Firms are confronting an ever changing and increasingly complex environment (Grant, 1996; O'Connor, 2008). ACAP enables firms to better respond and persist in such dynamic complexity (Cohen \& Levinthal, $1989,1990)$. It acts as a funneling or screening mechanism to productively utilize external knowledge for organizational advantage (Lane \& Lubatkin, 1998; Zahra \& George, 2002). This utilization involves a pathway from the identification and acquisition of external knowledge (exploratory learning), through its assimilation, understanding and retention (transformative learning) to its transmutation and application (exploitative learning) (Lane et al., 2006). While there are other ACAP frameworks available (e.g. Zahra \& George, 2002), we use Lane et al.'s (2006) framework because its focus on exploration as well as exploitation and the combination of the two through transformative learning is particularly useful in the context of organizations that promote new innovations and new products/services (see Gebauer, Worch, \& Truffer, 2012), such as the SMEs that we focused on.

In exploratory learning, firms capitalize on the available knowledge (Jansen et al., 2005; Lane et al., 2006). Exploratory learning requires firms to continuously scan the environment to identify and collect industry information, observe technological trends and identify sources of new knowledge. This exploratory search enables organizations to expand their horizon and acquire new knowledge from external sources. However, knowledge acquisition is a necessary, but not sufficient condition for knowledge application (McGrath, 2001). In the context of problem solving competence, Atuahene Gima and Wei (2011) argue that the mere generation of market knowledge will not affect new product performance unless project members have the ability to apply and use knowledge (Cassiman \& Veugelers, 2006; Daft \& Weick, 1984).

However, the pathway from the exploration of knowledge to its application requires knowledge to be analyzed, understood and retained (Argote, McEvily, \& Reagans, 2003; Garud \& Nayyar, 1994). This is achieved through transformative learning (Lichtenthaler, 2009). For this, organizations need to be proficient in quickly understanding and absorbing knowledge (see Brown \& Duguid, 1991). The knowledge that the firm assimilates in this process needs to be carefully stored and managed (March, 1991) as well as reactivated (Marsh \& Stock, 2006) for later use and exploitation (Lane et al., 2006). Critical to this reactivation is a well functioning knowledge management system (Iske \& Boekhoff, 2002). Moreover, in the current dynamic environment (Theodosiou, Kehagias, \& Katsikea, 2012), time is a critical element. Firms, therefore, need to constantly analyze and interpret changing market demands and quickly understand new opportunities in order to translate these into competitive products.

Finally, knowledge application and use requires firms to be proficient in translating knowledge into new products and services. Exploitative learning of ACAP captures this translation process (Lane et al., 2006) through the transmutation of knowledge assimilated earlier and its subsequent application (Lichtenthaler, 2009). This translation is a dynamic rather than static process, involving frequent interactions within and outside the organization (Molina Morales \& Martínez Fernández, 2010) where firms share expertise and capabilities, and subsequently improve and refine knowledge. Firms in this process require receptivity to new ideas (Tajeddini \& Trueman, 2008) to regularly apply new knowledge in new products. Firms are also required to continuously learn (Lane et al., 2006) from their experiences and those of others to exploit knowledge better. Since learning is a self reinforcing process of knowledge creation (Akbar, 2003; Glazer, 1991), it makes it easier for firms to implement new knowledge. As such ACAP increases the speed at which firms can innovate (Lane et al., 2006).

\subsection{Technological capability, absorptive capacity and performance}

Technological capability is the ability to perform any relevant technical function or volume activity within the firm including the ability to develop new products and processes, and to operate facilities effectively (Teece et al., 1997). Technological capability is becoming extremely important because responding to dynamic market needs requires the development of new products that are increasingly nested in new technologies (Hsieh \& Tsai, 2007) and such technologies change very rapidly (Handfield \& Bechtel, 2002), thereby necessitating firms to keep abreast with this technological change. Firms with well developed technological capabilities tend to be high performing (Lavie, Kang, \& Rosenkopf, 2011; McEvily, Eisenhardt, \& Prescott, 2004) because mastering state of the art technologies allows them to pioneer in process innovations leading to competitive advantage through efficiency gains (Teece et al., 1997). They are also more innovative (Afuah, 2002) and can achieve higher differentiation by innovating products in response to the changing market environment (Teece \& Pisano, 1994; Verona, 1999).

Technological capability relates to ACAP's exploratory, transformative and exploitative learning (Liu et al., 2013; Zhou \& Wu, 2010). Developing a firm's technological capability requires investments in R\&D which helps in the exploration of new innovations (Afuah, 2002). When a firm develops its technological capability, it is more likely to be receptive to new external information (Berkhout, Hartmann, \& Trott, 2010). This receptivity further increases the ability of the firm to identify new technological developments and trends as a reinforcing 
cycle of exploratory innovation whereby the speed with which the firm is able to discover new opportunities and respond to technological changes increases (Rosenkopf \& Nerkar, 2001; Veugelers, 1997). Thus, the higher the level of technological capability, the higher is the firm's likelihood of engaging in exploratory innovation (Lavie \& Rosenkopf, 2006). At the same time, developing a firm's technological capability involves knowledge to be accumulated and stored (Afuah, 2002). The accumulation of technological knowledge not only increases product innovation skills, but also the firm's ability to engage in the transformation process through evaluation, use and implementation of new technologies (Zahra \& George, 2002). Similarly, Rothaermel and Deeds (2004) find that an entrepreneurial venture with strong technological capabilities tends to engage in more exploitation alliances to gain access to complementary assets such as manufacturing. As firms accumulate more knowledge and experience, they become more efficient in deploying their existing knowledge (Benner \& Tushman, 2003) and, thus, generate more exploitative activities due to the self reinforcing nature of learning (Zhou \& Wu, 2010). Thus, the higher the level of technological capability of the firm in a particular field, the higher the likelihood that it will foster more exploitation in that field (Levinthal \& March, 1993). The role of technological capability to foster both exploration and exploitation closely resembles the ambidextrous view of learning and innovation. Ambidexterity in learning and innovation combines exploration and exploitation even though the former requires openness and divergence whereas the latter requires closure and convergence (see Lin, McDonough, Lin, \& Lin, 2013). Technological capability by contributing both to exploratory and exploitative learning promotes ambidexterity, thereby helping the firm to identify, evaluate and select external information and technologies for adoption, that is, its ACAP. At the same time, the technological capability could also be associated with a firm's performance. Fernhaber and Patel (2012), for example, in the context of complex innovations found that ambidexterity, along with ACAP, enhances the benefits of complex innovations and mitigates the cost of associated with their increased complexity. Technological capability by promoting ambidexterity could contribute positively to the firm's innovative and financial performance. Thus, we suggest the following hypotheses:

Hypothesis 1. A firm's technological capability has a positive relationship with its absorptive capacity.

Hypothesis 2. A firm's technological capability has a positive relationship with its performance.

\subsection{Customer relationship capability, absorptive capacity and performance}

Customer relationship capability is the ability of the firm to establish, maintain and harness value-based relationships with end users and other stakeholders in the supply chain (Day, 2002; Mentzer et al., 2001). With increasing competition, it is imperative for firms to adopt a customer focus (Payne \& Frow, 2005). Customer relationships require firms to focus on key customers, as well as fully understand and satisfy their needs and requirements on a continuous basis (Goldsmith, 2010). The aim is for the firm to ensure customer retention and loyalty (Kumar \& Shah, 2004; Verhoef, 2003) based on customer satisfaction, which is a key determinant in customers' decisions on whether or not to continue a business relationship (Rust, Zahorik, \& Keiningham, 1995). The key in this process is the firm's ability to deliver value which matches buyer's expectations and perception of a product's performance (Kumar, Scheer, \& Kotler, 2000). The greater this match, the greater the customer satisfaction. However, the more this match occurs repeatedly, the more customer loyalty is generated (Homburg, Koschate, \& Hoyer, 2005; Paulssen \& Birk, 2007). The firm is therefore able to develop lasting, long term customer relationships, based on cumulative customer satisfaction over time (Reinartz \& Kumar, 2000, 2002, 2003).
Customer relationship capability is an important source for a firm's ACAP. The primary input of ACAP is external knowledge inflows (Kostopoulos et al., 2010). ACAP also involves how this external knowledge is used for exploring new ideas and integrating and implementing these ideas (Lichtenthaler, 2009) for their translation into useful products and services (Zahra \& George, 2002). Customer relationship capability enables the firm to do just that. It is inherently focused on customers and by identifying their needs and requirements it essentially involves a constant search for market knowledge (Berkhout et al., 2010), which helps firms to select strategies to match these needs by developing innovative products and services that deliver real value to the customers (see Lane et al., 2006; Zahra \& George, 2002). Tsai, Chou, and Kuo (2008) note that absorptive capacity is enhanced when firms have the skills and procedures to understand and satisfy the expressed needs of current customers. Moreover, customer needs are not static but are likely to be dynamic and thus evolve over time. Thus, important in the value creation for customers is the continuous adaptation of products and services based on their evolving needs (Stringfellow, Nie, \& Bowen, 2004). Customer relationship capability involves a continuous process of market search to identify customer needs and changes in customer tastes and preferences.

Customer relationship capability is also likely to have an association with a firm's performance. It is widely accepted that development of strong relationships with customers, often through a customer relationship management approach, is positively related with performance (Reinartz, Krafft, \& Hoyer, 2004; Ryals, 2005). Customer relationship capability allows the firm to acquire knowledge about customers and creatively use this knowledge to develop new products and services (Anderson \& Srinivasan, 2003; Ernst, Hoyer, Krafft, \& Krieger, 2011). Berkhout et al. (2010) note that the successful development and diffusion of innovative new products usually stem from insights related to understanding potential customers and their marketing needs. Augusto and Coelho (2009) found that customer orientation is an important driver of a firm's new to the world product innovation. Customer relationship capability by helping firms to match products and services with customer needs allows firms to deliver real value to the customers, which in turn is likely to positively contribute to the firm's performance. Thus, we suggest the following hypotheses:

Hypothesis 3. A firm's customer relationship capability has a positive relationship with its absorptive capacity.

Hypothesis 4. A firm's customer relationship capability has a positive relationship with its performance.

\subsection{Organizational performance and absorptive capacity}

Firms that successfully search the environment and identify unaddressed market gaps are likely to have an advantage over competitors (Dickson, 1992), as they can better align their resource deployments with their market environment (Eisenhardt \& Martin, 2000). Therefore, one would expect that firms which have appreciated and developed their ACAP will be in a better position to capture and utilize opportunities in a dynamic environment (Jansen, Van Den Bosch, \& Volberda, 2006) and translate these opportunities into profitable products and services (Escribano et al., 2009; Fosfuri \& Tribó, 2008; Lichtenthaler, 2009; Zahra \& George, 2002). Barriers to the development of ACAP could reduce agility and flexibility of the firm to respond to fast changing markets (Matthyssens, Pauweis, \& Vandenbempt, 2005). Following these suggestions, we focus on ACAP's relationship with a firm's overall organizational performance in terms of NPD program, customer satisfaction and financial performance.

An important aspect of a firm's performance is its NPD program. Firms with well performing and efficient NPD programs are more likely than their competitors to create new products and services 
(Vorhies \& Morgan, 2005). The creation of new products and services involves the combination of external and internal knowledge of the organization (Nonaka \& Takeuchi, 1995; Nonaka, Toyama, \& Hirata, 2008). Earlier, ACAP was associated with a firm's innovative capabilities and innovation performance (Cohen \& Levinthal, 1989, 1990). Studies argued that ACAP increases both the frequency and speed of innovations (Lane et al., 2006; Tsai, 2001). Firms with higher levels of ACAP (or highly capable companies) have higher innovative performance than those with lower levels of ACAP (or lowly capable companies) (Chen, Lin, \& Chang, 2009). While studies have identified the positive association between ACAP and innovative performance (number of new products introduced or annual sales from new products) (Alegre, Sengupta, \& Lapiedra, 2013; Kostopoulos et al., 2010; Tsai, 2001), new product programs have received scant attention in the literature (Lane et al., 2006). Only recently, Cepeda Carrion et al. (2012) in an empirical study of 286 large Spanish companies showed that ACAP is an important dynamic determinant for a company's encouragement, support and acceptance to develop new products and services. This role of ACAP may also apply to high-technology firms. Nieto and Santamaria (2010) for instance, found that technological collaboration for obtaining external knowledge is positively associated with a firm's innovativeness.

Another important aspect of organizational performance is customer satisfaction. Firms that are responsive to fast changing customer preferences (Theodosiou et al., 2012) are more likely to perform well compared to their competitors (Srinivasan, Pauwels, Sliva Risso, \& Hanssens, 2009). Important in this process is the ability of the firm to process market information (Hart, Tzokas, \& Saren, 1999; Hult, Ketchen, \& Slater, 2005). For instance, a firm's market orientation, that is, the extent to which it engages in the generation, dissemination and response to market intelligence related to current and future customer needs (Kohli \& Jaworski, 1990) enables the firm to have a greater understanding of, customer wants and needs (Hult \& Ketchen, 2001; Jaworski \& Kohli, 1993). ACAP by enabling firms to identify, acquire, analyze, understand, and creatively apply external knowledge (Lane et al., 2006), is likely to allow firms to carefully select its customers, identify their needs, develop products tailored to their needs, and communicate as well as deliver greater value to their customers, thereby generating greater customer loyalty and satisfaction.

Also important for firms is the profitability of new products and services. Profitability is important because firms increasingly face intense competition in markets (Calantone, Yeniyurt, Townsend, \& Schmidt, 2010) and a high rate of technological change (Eng \& Quaia, 2009). Thus, the financial advantage from the innovations could be crucial to the survival of the firm. However, such financial advantage is not always guaranteed (Baker \& Sinkula, 2005), and the number of new products that a firm is able to introduce may or may not be the same as higher returns on investments (Tsai, 2001). Firms that undertake investments in developing their ability to explore, develop and exploit new products and services are more likely to generate financial benefits, although with possible lag effects (Cohen \& Levinthal, 1990). Recent evidence suggests a positive relationship between ACAP and financial performance (Lane et al., 2006; Zahra \& George, 2002). For instance, Kostopoulos et al. (2010) found ACAP contributing directly as well as indirectly to financial performance. Lichtenthaler (2009) found a positive relationship between ACAP's exploratory, exploitative and transformative learning and financial performance, with differences in levels under different environmental turbulence.

Given ACAP's role in positively affecting a firm's overall performance in terms of the NPD performance, customer satisfaction and profitability, we suggest the following hypothesis:

Hypothesis 5. The absorptive capacity of a firm has a positive relationship with its performance.

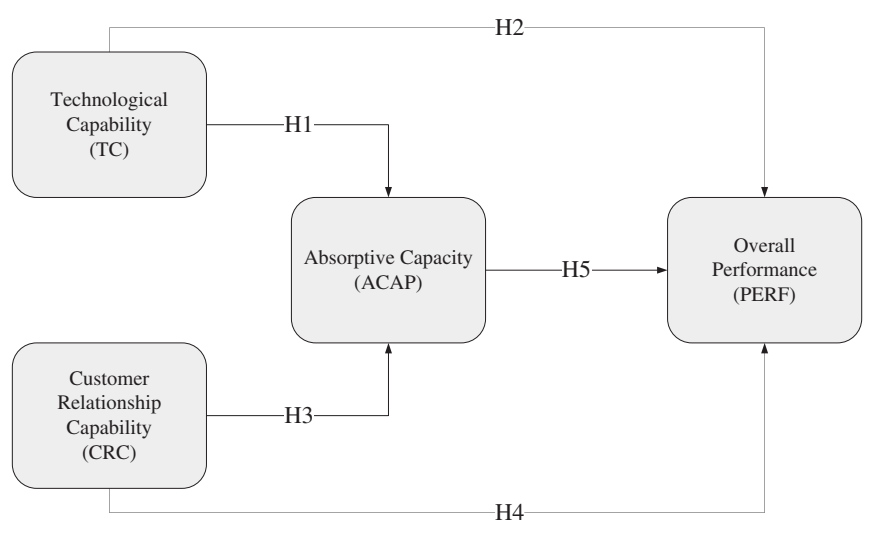

Fig. 1. The conceptual model.

Fig. 1 below depicts the study's conceptual framework and illustrates the hypothesized relationships. As shown in the framework and discussed earlier, we explore the overall assumption that the more a firm has a clear ability to use various technologies (TC) and capitalize on a deep understanding of its customer base (CRC), the higher its capacity to explore, integrate and exploit (ACAP) external technologies and the better its product, market and financial performance (PERF).

\section{Methodology}

Primary data for this study were collected in 2011 at the Semicon Korea and Led Korea annual exhibitions as they comprise South East Asia's largest semiconductor industry events. Committed to the manufacturing of advanced microelectronics, both exhibitions are organized by Semiconductor Equipment and Materials International (SEMI). Four overarching interconnected categories encompass the semiconductor industry in South Korea; that is, integrated device manufacturers (IDM), fabless manufacturers, foundry companies and, lastly, equipment and materials manufacturers including assembly and packaging firms. According to Invest Korea (2010), the semiconductor industry accounted for $11.3 \%$ of the global market share in 2009, and in 2010, it accounted for $10.9 \%$ of South Korea's overall exports.

A drop and collect survey method (Ibeh, Brock, \& Zhou, 2004) targeting the 408 exhibiting SMEs (employing less than 250 persons) was employed at both exhibitions. Two informants per exhibiting SME were identified and invited to complete a questionnaire. While the distributed finalized questionnaire was in Korean, the initial draft was prepared and piloted in English in the United Kingdom. The ensuing Korean translation was piloted in South Korea, amended accordingly and finally back translated to English by an independent bilingual speaker.

Completed questionnaires were collected at a time agreed with the exhibitors on the last day of the exhibitions. Such an approach enabled the highly effective $53.7 \%$ response rate equivalent to 219 SMEs. The analysis in this study focuses on the sub sample of 158 SMEs (316 questionnaires) that are Korean owned and fabless. While we acknowledge the limitations of this concentration, doing so enhanced the focus of research and decreased heterogeneity of estimates issues (Bass, Cattin, \& Wittink, 1978).

Overall, the average age of the firms in our effective sample was 16.38 years, while $80 \%$ of the respondents in the effective sample where CEOs (24\%), senior managers $(43 \%)$, managers $(13 \%)$ or employees (20\%), with an average time with the firm of 4.97 years. Variables were measured by means of Likert-type scales ranging from 1 to 5 , where $1=$ strongly disagree and $5=$ strongly agree. Scales were adapted or developed from existing literature (see Appendix A). Absorptive capacity (ACAP) was based on questions adapted from the works of Jansen et al. (2005), Todorova and Durisin (2007), and Lichtenthaler (2009). Technological capability (TC) was measured 
with a four item construct based on insights from the works of Tsai (2004), Ortega (2010), and Zhou and Wu (2010). Customer relationship capability (CRC) was measured with a four item construct based on insights from the works of Ryals (2005), Reinartz et al. (2004), and Reimann, Schilke, \& Thomas (2010). In both TC and CRC measures, the scales used ranged from 1 to 5 , where $1=$ much worse than competitors and $5=$ much better than competitors. Lastly, performances of the NPD program, market performance and profitability compared to major competitors (Scale 1 to 5, as in Vorhies and Morgan (2005)) were reflected in 12 items.

\section{Analysis and results}

The MPlus (www.statmodel.com) Exploratory Structural Equation Modeling [ESEM] technique (Asparouhov \& Muthén, 2009; Muthén \& Muthén, 2010) was used to establish the internal consistency of our measures as it combines exploratory and confirmatory factor analysis in one procedure and avoids the problems associated with the traditional two step process documented by Fornell and Yi (1992).

For a measurement model to have sufficiently good model fit (Fornell \& Larcker, 1981), the root mean square error of approximation (RMSEA) should be less than 0.08 , the chi-square value normalised by degrees of freedom ( $\chi^{2} / \mathrm{df}$ ) should not exceed 5 , and the comparative fit index (CFI) should exceed 0.9. For the current CFA model, RMSEA was $0.039, \chi^{2} / \mathrm{df}$ was $1.24\left(\chi^{2}=304 ; \mathrm{df}=245\right)$, and CFI was 0.995, suggesting adequate model fit.

The convergent validity of the scales was verified based on the use of the three criteria suggested by Fornell and Larcker (1981): all indicator loadings should be significant and exceed 0.7 , construct reliabilities should exceed 0.8 , and average variance extracted (AVE) by each construct should exceed the variance due to measurement error for that construct. For the used CFA model, all loadings were above the 0.7 threshold. The composite reliabilities of the constructs ranged between 0.92 and 0.96 , and AVE ranged from 0.87 to 0.93 (see Table 1). Therefore, all the three conditions for convergent validity were met.

Discriminant validity was assessed using the guideline suggested by Fornell and Larcker (1981): the square root of the AVE from the construct should be greater than the correlation shared between the construct and other constructs in the model. Table 1 lists the correlations among the constructs, with the square root of the AVE on the diagonal. All the diagonal values exceed the inter construct correlations.

We avoided common methods bias (Podsakoff \& Organ, 1986) as follows. First, we used Harman's one factor test and no single one factor was found. Second, dependent variables were included at the end of the questionnaire to avoid post hoc rationalization. Finally, we collected data from two informants in each firm. One informant provided information about the absorptive capacity of the firm while the second informant provided information about the performance of the firm (dependent variable) and its technological and customer relationship capability.

Table 1

Composite reliability and discriminant validity.

\begin{tabular}{llllllllllll}
\hline Item & Mean & SD & CR & EL & TL & EXL & TC & CRC & NPDP & MP & FP \\
\hline EL & 4.04 & .77 & .92 & $\mathbf{. 8 7}$ & & & & & & & \\
TL & 3.89 & .77 & .93 & $.65^{* *}$ & $\mathbf{. 9 1}$ & & & & & & \\
EXL & 3.78 & .84 & .95 & .63 & .77 & $\mathbf{. 8 8}$ & & & & & \\
TC & 4.00 & .83 & .96 & .43 & .53 & .51 & $\mathbf{. 9 3}$ & & & & \\
CRC & 4.14 & .71 & .94 & .42 & .51 & .50 & .74 & $\mathbf{. 9 0}$ & & & \\
NPDP & 3.98 & .77 & .96 & .43 & .53 & .51 & .65 & .67 & $\mathbf{. 9 2}$ & & \\
MP & 4.04 & .66 & .95 & .45 & .55 & .54 & .68 & .70 & .75 & $\mathbf{. 9 1}$ & \\
FP & 3.78 & .70 & .95 & .33 & .40 & .39 & .50 & .51 & .54 & .57 & $\mathbf{. 9 2}$
\end{tabular}

Squared Roots of AVE. Bold is in place to distinguish them from the correlation coefficients which are marked with ** and not bold.

$\mathrm{CR}=$ composite reliability, $\mathrm{EL}=$ exploratory learning, $\mathrm{TL}=$ transformative learning, $\mathrm{EXL}=$ exploitative learning, $\mathrm{TC}=$ technological capability, $\mathrm{CRC}=$ customer relationship capability, $\mathrm{NPDP}=\mathrm{NPD}$ performance, MP: market performance, $\mathrm{FP}=$ financial performance.
The fit statistics for the structural model had a satisfactory fit to the data, with CFI values larger than 0.90, an RMSEA value below .08 and WRMR below 1.0. Specifically, fit indices were as follows: $\mathrm{CFI}=0.997$, RMSEA $=0.024$ and WRMR $=0.73$. Standardized path coefficients with associated errors in brackets are presented in the following Table 2.

Hypotheses 1 and 3 argued that (H1) the technological capability (TC) and (H3) the customer relationship capability (CRC) of the firm increase the firm's absorptive capacity (ACAP). We found support for these hypotheses. Similarly, we found support for hypotheses 2, 4 and 5 where it was postulated that the technological (H2) and customer relationship capability of the firm (H4) as well as its absorptive capacity (H5) enhance the overall performance of the firm.

Given the nature of the overall argument, we proceeded to test for the mediating role of absorptive capacity on the relationship between the technological and customer relationship capability of the firm upon its overall performance. We used a technique recommended by Preacher and Hayes $(2004,2008)$, which examines the indirect effect between the predictor and the criterion variables through the mediator(s) by employing a bootstrapping routine. The results of this analysis are provided in Table 2, including estimates of the indirect effects, along with the bias corrected bootstrapped confidence intervals for the mediated path estimates (MacKinnon, Lockwood, \& Williams, 2004). These results confirm the mediating role of absorptive capacity albeit only for its mediation in the relationship between technological capability of the firm and its overall performance.

Overall, the structural model provides confirmation of the influence of technological and customer relationship capability on the absorptive capacity of the firm as well as their direct relationship with the firm's overall performance. Moreover, the influence of absorptive capacity on the overall performance of the firm was also confirmed as well as its mediation role in the relationship between technological capability and overall performance of the firm.

\section{Conclusions, implications and limitations}

Based on Cohen and Levinthal's (1990) original definition of recognizing, assimilating and applying external knowledge, the concept of absorptive capacity (ACAP) has been diffused widely in management. Despite such widespread acceptance, Sun and Anderson (2010) recently reiterated the need for more integrated approaches to ACAP and stressed again earlier warnings about the dangers of theoretical fragmentation in organizational studies (Hambrick, 2004). As a result, there is growing acceptance of the considerable value in researching ACAP within the wider organizational fabric of the firm in a variety of industrial contexts. In particular, the need to expand our understanding of the antecedents of ACAP and its influence upon performance in the context of SMEs operating in technologically intensive industries has been advocated widely (Flatten, Greve, \& Brettel, 2011; Fosfuri \& Tribó, 2008; Liao, Welsch, \& Stoica, 2003).

The study reported here was guided by these considerations. Based on its results, the study provides important evidence in support of the interplay between absorptive capacity, technological and customer relationship capability and their contribution to the firms' overall performance. The structural pattern that emerged points to the fact that better performance should be expected by firms that have managed to accompany their effort to engage with externally held knowledge with the lenses of a strong technological and customer relationship capability. Interestingly, the best fit model directs attention to the interaction between technological and customer relationship capability. The mediating role of ACAP in the relationship between technological capability and performance was also confirmed.

\subsection{Theoretical contributions}

In addressing the above mentioned gaps, this study contributes to theory in four ways. 
Table 2

Path coefficients and indirect effects.

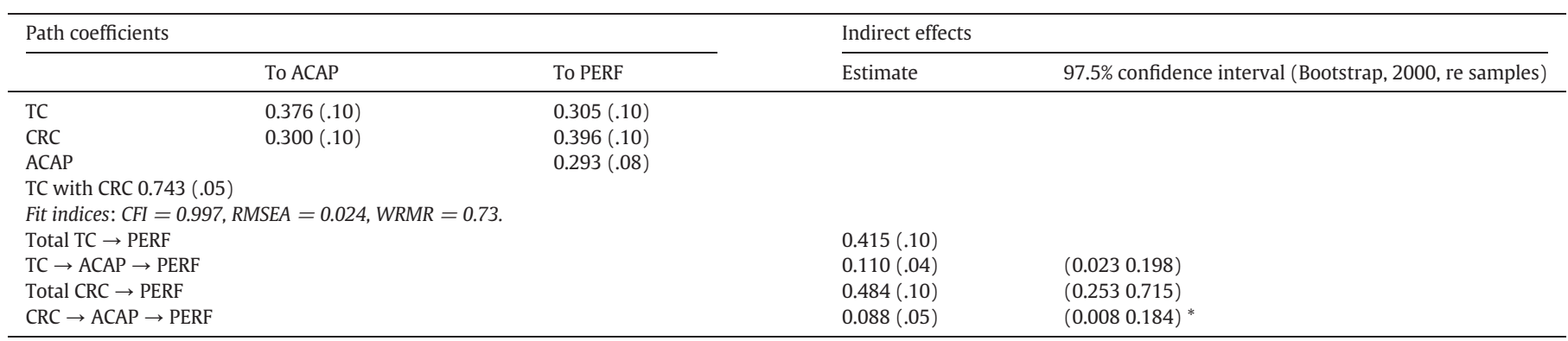

$\mathrm{TC}=$ technological capability, $\mathrm{CRC}=$ customer relationship capability, $\mathrm{ACAP}=$ absorptive capacity, $\mathrm{PERF}=$ performance.

${ }^{*}$ No mediation effect.

First, it advances our current understanding of organizational antecedents impacting on ACAP and its influence upon the performance of the firm. By investigating the effects of TC and CRC on ACAP, this study introduces important organizational antecedents of ACAP which, although postulated, have not been systematically investigated (Cohen \& Levinthal, 1990; Jansen et al., 2005; Lane et al., 2006; Van den Bosch, Volberda, \& de Boer, 1999). In doing so, our study provides greater currency to the observation that ACAP is productively building upon the internal resources of the firm (Lane et al., 2006; Zahra \& George, 2002). Furthermore, the identified interplay among technological capability, customer relationship capability and absorptive capacity provides safer ground for researchers advocating the need for higher integration of ACAP with other important elements of the firm such as organizational learning, resources and capabilities (see also Sun \& Anderson, 2010).

Second, it embeds absorptive capacity alongside well-established capabilities that have been identified in marketing management as critical to the success of a firm's new product development activity. Such positioning helps establish theoretical integration of the concept of ACAP and the NPD activities of the firm, which in turn warrants understanding of its unique influence and by implication its wider acceptance.

Third, the study contributes to the literature on the resource-based view of the firm (Jansen et al., 2006; Kogut \& Zander, 1992) by identifying and testing unique pathways through which managers can enhance their firm's ACAP, as well as pathways through which ACAP contributes ultimately to the overall performance of the firm. Therefore, this study constitutes a significant contribution to enhancing our understanding of the condition underlying ACAP's becoming a source of competitive advantage (Cassiman \& Veugelers, 2006; Escribano et al., 2009). This is further enhanced by the findings of this study as regards the mediating role of ACAP in the relationship between technological capability and performance of the firm.

Finally, by researching these issues in a sample of SMEs from the South Korean semiconductor industry, this study contributes contextually diverse evidence which helps enhance application of the theory of absorptive capacity. Indeed, the study contributes to an increasing body of literature on ACAP's outcomes (e.g., Arbussà \& Coenders, 2007; Fosfuri \& Tribó, 2008; Lichtenthaler, 2009) by adding empirical evidence from technology-intensive firms. Moreover, by concentrating on a unique context as reflected by the sample of high-tech SMEs in the South Korean semiconductor industry, this study contributes towards a more robust theory of ACAP.

\subsection{Practical contributions}

For managers of technology-intensive SMEs, there is a very useful lesson alongside associated resource allocation guidance. That is, if they wish to have the best possible performance for their firm, they should navigate their firm's exploration and exploitation of external knowledge effort through the lenses of a balanced approach to their technological and customer relationship capability. Given the resource consuming character of ACAP, TC and CRC, and the apparent resource constraints of SMEs, managers will be able to better target their limited resources and achieve the highest benefits if they are guided by this study's findings as regards the interplay of TC, CRC and ACAP. Indeed instead of considering these as areas where expertise requires unique resources to develop, it should be acknowledged that there are synergies at play and multiplier effects through mediating relationships. For knowledge management practitioners within technology-intensive firm, the appreciation of the roles played by technological and customer relationship capability may allow them to engage better the expertise of both technical and marketing functions of the firm in the exploration, transformation and exploitation of external knowledge.

Appreciation of these unique influences of TC and CRC on ACAP will help managers harnessing greater value from any effort to enhancing their absorptive capacity and of course in doing so facilitate a more useful dialogue among marketing, knowledge and technical areas in their firms. Based on this research, the powerful argument that the more a firm has a clear ability to produce technologically superior products (TC) while capitalizing on a deep understanding of its customer base (CRC), the higher will be its capacity to explore, integrate and exploit (ACAP) external knowledge, and by implication the better its product, market and financial performance will be now seems not only logical but clearly justifiable and demonstrable.

Practically speaking, firms seeking to enhance their performance through their ACAP would be wise to do so in tandem with the development of their technological and customer relationship capability.

\subsection{Limitations and future research directions}

The results of this study and associated recommendations should be approached in view of the study's limitations emanating mainly from the type of its sampled firms and its snapshot nature. While the study addressed the lack of research on ACAP within high-tech SMEs, it is acknowledged that this reduces the generalizability of its results to other types of firms and industries. Furthermore, despite strong theoretical support for our hypotheses, the snapshot nature of this study directs us to recommend caution as regards causal inferences. To obtain a true appreciation of cause and effect relationships between the various constructs of this study, including performance, future researchers should use longitudinal data.

Such a longitudinal study may also allow researchers to go one step further and discover the influence of the actual processes used for enhancing the absorptive capacity as well as the required resources and associated configuration of resources for enabling enhanced performance.

Also, research on different technology-intensive industries and in other parts of the world would further enhance our understanding between ACAP and technological and customer relationship capability. 
Another valid research direction stems from ACAP's mediation role in our study. This raises questions as regards to other organizational constructs where ACAP may have a similar mediation effect. For example, the interplay between the strategic posture of the firm, such as its entrepreneurial orientation, and ACAP may provide additional insight as regards the antecedents of ACAP and its impact upon the performance of the firm. Notwithstanding here the research by Wales, Parida, and Patel (2013), combining entrepreneurial orientation, the technological and customer relationship capabilities of our research alongside ACAP, may allow us to explain the diminishing returns of ACAP. Particularly within high-tech small firms there is no doubt that more research to discover the complementarities between ACAP and other functional areas of the firm, may go some way to explain why despite equally applicable resource constraints some firms seem to master success with their new product development program better than others.

\section{Appendix A. Items used in studied constructs}

Technological capability [based on Tsai (2004), Ortega (2010), Zhou and Wu (2010)]

Acquiring important technologies

Identifying new technology opportunities

Responding to technology changes

Mastering state of the art technologies

Customer relationship capability [based on Ryals (2005), Reinartz et al. (2004), Reimann, Schilke and Thomas (2010)]

Strength of relationships with key customers

Customer loyalty

Understanding and responding to customer needs

Using customer knowledge to develop new products/services

Absorptive capacity [based on Jansen et al. (2005), Todorova and Durisin (2007), Lichtenthaler (2009)]

\section{Exploratory learning}

We frequently scan the environment for new technologies.

We thoroughly observe technological trends.

We observe in detail external sources of new technologies.

We thoroughly collect industry information.

Transformative learning

We are proficient in reactivating existing knowledge for new uses.

We quickly analyze and interpret changing market demands for our technologies.

New opportunities to serve our customers with existing technologies are quickly understood.

Exploitative learning

We are proficient in transforming technological knowledge into new products.

We regularly apply new technologies in new products.

We constantly consider how to better exploit new technologies.

We easily implement new technologies in new products.

Performance measures [based on Vorhies and Morgan (2005)]

\section{NPD performance}

The overall performance of our new product development program has met our objectives

Our new product development program is profitable

Compared with our major competitors our new product development program is more successful

The new product development program in this firm is performing well

Market performance

Overall customer satisfaction

Delivering value to our customers

Delivering what our customers want

Retaining valued customers

Overall financial performance

Overall business profitability

Reaching financial goals

Return on investment (ROI)

Return on sales (ROS)

\section{References}

Abecassis Moedas, C., \& Mahmoud Jouini, S. B. (2008). Absorptive capacity and source recipient complementarity in designing new products: An empirically derived framework. Journal of Product Innovation Management, 25(5), 473-490.

Afuah, A. (2002). Mapping technological capabilities into product markets and competitive advantage: The case of cholesterol drugs. Strategic Management Journal, 23(2), 171-179.

Akbar, H. (2003). Knowledge levels and their transformation: Towards the integration of knowledge creation and individual learning. Journal of Management Studies, 40(8), 1997-2021.

Alegre, J., Sengupta, K., \& Lapiedra, R. (2013). Knowledge management and innovation performance in a high tech SMEs industry. International Small Business Journal, 31(4), 454-470

Anderson, R. E., \& Srinivasan, S. S. (2003). E satisfaction and e loyalty: A contingency framework. Psychology and Marketing, 20(2), 122-138.

Arbussà, A., \& Coenders, G. (2007). Innovation activities, use of appropriation instruments and absorptive capacity: Evidence from Spanish firms. Research Policy, 36(10), $1545-1558$

Argote, L., McEvily, B., \& Reagans, R. (2003). Managing knowledge in organizations: An integrative framework and review of emerging themes. Management Science, 49(4), $571-582$.

Asparouhov, T., \& Muthén, B. (2009). Exploratory structural equation modeling. Structural Equation Modeling, 16(3), 397-438.

Atuahene Gima, K., \& Wei, Y. (2011). The vital role of problem solving competence in new product success. Journal of Product Innovation Management, 28(1), 81-98.

Augusto, M., \& Coelho, F. (2009). Market orientation and new to the world products: Exploring the moderating effects of innovativeness, competitive strength, and environmental forces. Industrial Marketing Management, 38(1), 94-108.

Baker, W. E., \& Sinkula, J. M. (1999). The synergistic effect of market orientation and learning orientation on organizational performance. Journal of the Academy of Marketing Science, 27(4), 411-427.

Baker, W. E., \& Sinkula, J. M. (2005). Market orientation and the new product paradox. Journal of Product Innovation Management, 22(6), 483-502.

Bass, F. M., Cattin, P. J., \& Wittink, D. R. (1978). Firm effects and industry effects in the analysis of market structure and profitability. Journal of Marketing Research, 15(1), 3-10.

Benner, M. J., \& Tushman, M. L. (2003). Exploitation, exploration and process management: The productivity dilemma revisited. Academy of Management Review, 28(2), 238-256.

Berkhout, G., Hartmann, D., \& Trott, P. (2010). Connecting technological capabilities with market needs using a cyclic innovation model. RED Management, 40(5), 474-490.

Brown, J. S., \& Duguid, P. (1991). Organizational learning and communities of practice: Toward a unified view of working, learning, and innovation. Organization Science, 2, 40-57.

Calantone, R. J., Yeniyurt, S., Townsend, J. D., \& Schmidt, J. (2010). The effects of competition in short product life cycle markets: The case of motion pictures. Journal of Product Innovation Management, 27(3), 349-361.

Camisón, C., \& Forés, B. (2010). Knowledge absorptive capacity: New insights for its conceptualization and measurement. Journal of Business Research, 63(7), 707-715.

Cassiman, B., \& Veugelers, R. (2006). In search of complementarity in the innovation strategy: Internal R\&D and external knowledge acquisition. Management Science, 52(1), $68-82$.

Cepeda Carrion, G., Cegarra Navarro, J. G., \& Jimenez Jimenez, D. (2012). The effects of absorptive capacity on innovativeness: Context and information systems capability as catalysts. British Journal of Management, 23(1), 110-129.

Chen, Y. S., Lin, M. J. J., \& Chang, C. H. (2009). The positive effects of relationship learning and absorptive capacity on innovation performance and competitive advantage in industrial markets. Industrial Marketing Management, 38(2), 152-158.

Cohen, W. M., \& Levinthal, D. A. (1989). Innovation and learning: The two faces of R\&D. The Economic Journal, 99(397), 569-596.

Cohen, W. M., \& Levinthal, D. A. (1990). Absorptive capacity: A new perspective on learning and innovation. Administrative Science Quarterly, 35(1), 128-152.

Cooper, R. \& Kleinschmidt, E. (1995). Benchmarking the firm's critical success factors in new product development. Journal of Product Innovation Management, 12(5), 374-391.

Daft, R. L., \& Weick, K. E. (1984). Toward a model of organizations as interpretation systems. Academy of Management Review, 9(2), 284-295.

Day, G. (2002). Creating a superior customer relating capability. MIT Sloan Management Review, 44(3), 77-82.

Dickson, P. (1992). Towards a general theory of competitive rationality. Journal of Marketing, 56(1), 69-83.

Eisenhardt, K. M., \& Martin, J. A. (2000). Dynamic capabilities: What are they? Strategic Management Journal, 21(10/11), 1105-1121.

Eng, T. Y., \& Quaia, G. (2009). Strategies for improving new product adoption in uncertain environments: A selective review of the literature. Industrial Marketing Management, $38(3), 275-282$

Ernst, H., Hoyer, W., Krafft, M., \& Krieger, K. (2011). Customer relationship management and company performance-the mediating role of new product performance. Journal of the Academy of Marketing Science, 39(2), 290-306.

Escribano, A., Fosfuri, A., \& Tribó, J. A. (2009). Managing external knowledge flows: The moderating role of absorptive capacity. Research Policy, 39(1), 96-105.

Fernhaber, S. A., \& Patel, P. (2012). How do young firms manage product portfolio complexity? The role of absorptive capacity and ambidexterity. Strategic Management Journal, 33(13), 1516-1539. 
Flatten, T. C., Greve, G. I., \& Brettel, M. (2011). Absorptive capacity and firm performance in SMEs: The mediating influence of strategic alliances. European Management Review, 8(2), 137-152.

Fornell, C., \& Larcker, D. F. (1981). Structural equation models with unobserved variables and measurement error: Algebra and statistics. Journal of Marketing Research, 18(3), 382-388.

Fornell, C., \& Yi, Y. (1992). Assumptions of the two step approach to latent variable modelling. Sociological Methods \& Research, 20(3), 291-320.

Fosfuri, A., \& Tribó, J. A. (2008). Exploring the antecedents of potential absorptive capacity and its impact on innovation performance. Omega, 36(2), 173-187.

Garud, R., \& Nayyar, P. R. (1994). Transformative capacity: Continual structuring by intertemporal technology transfer. Strategic Management Journal, 15(5), 365-385.

Gebauer, H., Worch, H., \& Truffer, B. (2012). Absorptive capacity, learning processes and combinative capabilities as determinants of strategic innovation. European Management Journal, 30(1), 57-73.

Glazer, R. (1991). Marketing in an information intensive environment: Strategic implications of knowledge as an asset. Journal of Marketing, 55(4), 1-19.

Goldsmith, R. E. (2010). The goals of customer relationship management. International Journal of Customer Relationship Marketing and Management, 1(1), 16-27.

Grant, R. M. (1996). Prospering in dynamically competitive environments: Organizational capability as knowledge integration. Organization Science, 7(4), 375-387.

Hambrick, D. C. (2004). The disintegration of strategic management: It's time to consolidate our gains. Strategic Organization, 2(1), 91-98

Handfield, R. B., \& Bechtel, C. (2002). The role of trust and relationship structure in improving supply chain responsiveness. Industrial Marketing Management, 31(4), 367-382.

Hart, S., Tzokas, N., \& Saren, M. (1999). The effectiveness of market information in enhancing new product success rates. European Journal of Innovation Management, 2(1), 20-35.

Homburg, C., Koschate, N., \& Hoyer, D. W. (2005). Do satisfied customers really pay more? A study of the relationship between customer satisfaction and willingness to pay. Journal of Marketing, 69(2), 84-96.

Hsieh, M. H., \& Tsai, K. H. (2007). Technological capability, social capital and the launch for innovative products. Industrial Marketing Management, 36(4), 493-502.

Hull, C. E., \& Covin, J. G. (2010). Learning capability, technological parity, and innovation mode use. Journal of Product Innovation Management, 27(1), 97-114.

Hult, G. T., \& Ketchen, D. J., Jr. (2001). Does market orientation matter? A test of the relationship between positional advantage and performance. Strategic Management Journal, 22(9), 899-906.

Hult, G. T., Ketchen, D. J., Jr., \& Slater, S. F. (2005). Market orientation and performance: An integration of disparate approaches. Strategic Management Journal, 26(12), 1173-1181.

Ibeh, K., Brock, J. K. U., \& Zhou, Y. J. (2004). The drop and collect survey among the industrial population: Theory and empirical evidence. Industrial Marketing Management, 33(2), 155-165

Iske, P., \& Boekhoff, T. (2002). The value of knowledge doesn't exist: A framework for valuing the potential of knowledge. Practical Aspects of Knowledge Management, 2569, 632-638.

Jansen, J. J. P., Van den Bosch, P. A. J., \& Volberda, H. W. (2005). Managing potential and realized absorptive capacity: How do organizational antecedents matter? Academy of Management Journal, 48(6), 999-1015.

Jansen, J. J. P., Van Den Bosch, P. A. J., \& Volberda, H. W. (2006). Exploratory innovation, exploitative innovation, and performance: Effects of organizational antecedents and environmental moderators. Management Science, 52(11), 1661-1674.

Jaworski, B. J., \& Kohli, A. K. (1993). Market orientation: Antecedents and consequences. Journal of Marketing, 57(3), 53-70.

Kogut, B., \& Zander, U. (1992). Knowledge of the firm, combinative capabilities, and the replication of technology. Organization Science, 3(3), 387-397.

Kohli, A. K., \& Jaworski, B. J. (1990). Market orientation: The construct, research propositions and managerial implications. Journal of Marketing, 54(2), 1-18.

Kostopoulos, K., Papalexandris, A., Papachroni, M., \& Ioannou, G. (2010). Absorptive capacity, innovation and financial performance. Journal of Business Research, 64(12), 1335-1343.

Kotabe, M., Jiang, C. X., \& Murray, J. Y. (2014). Examining the complementary effect of political networking capability with absorptive capacity on the innovative performance of emerging market firms. Journal of Management. http://dx.doi.org/10.1177 0149206314548226 (Published online September 2).

Kumar, N., Scheer, L., \& Kotler, P. (2000). From market driven to market driving. European Management Journal, 18(2), 129-142.

Kumar, V., \& Shah, D. (2004). Building and sustaining profitable customer loyalty for the 21st century. Journal of Retailing, 80(4), 317-330.

Lane, P. J., Koka, B. R., \& Pathak, S. (2006). The reification of absorptive capacity: A critical review and rejuvenation of the construct. Academy of Management Review, 31(4), 833-863.

Lane, O. J., \& Lubatkin, M. (1998). Relative absorptive capacity and interorganizational learning. Strategic Management Journal, 19(5), 461-477.

Lane, P. J., Salk, J. E., \& Lyles, M. A. (2001). Absorptive capacity, learning and performance in international joint ventures. Strategic Management Journal, 22(12), 1139-1161.

Lavie, D., Kang, J., \& Rosenkopf, L. (2011). Balance within and across domains: The performance implications of exploration and exploitation in alliances. Organization Science, 22(6), 1517-1538

Lavie, D., \& Rosenkopf, L. (2006). Balancing exploration and exploitation in alliance formation. Academy of Management Journal, 49(4), 797-818.

Levinthal, D. A., \& March, J. G. (1993). The myopia of learning. Strategic Management Journal, 14(S2), 95-112.

Liao, J., Welsch, H., \& Stoica, M. (2003). Organizational absorptive capacity and responsiveness: An empirical investigation of growth oriented SMEs. Entrepreneurship: Theory and Practice, 28(1), 63-85.
Lichtenthaler, U. (2009). Absorptive capacity, environmental turbulence, and the complementarity of organizational learning processes. Academy of Management Journal, 52(4), 822-846.

Lin, H. E., McDonough, E. F., III, Lin, S. J., \& Lin, C. Y. Y. (2013). Managing the exploitation/ exploration paradox: The role of a learning capability and innovation ambidexterity. Journal of Product Innovation Management, 30(2), 262-278.

Liu, H., Ke, W., Wei, K. K., \& Hua, Z. (2013). The impact of IT capabilities on firm performance: The mediating roles of absorptive capacity and supply chain agility. Decision Support Systems, 54(3), 1452-1462.

MacKinnon, D. P., Lockwood, C. M., \& Williams, J. (2004). Confidence limits for the indirect effect: Distribution of the product and resampling methods. Multivariate Behavioral Research, 39(1), 99-128.

March, J. G. (1991). Exploration and exploitation in organizational learning. Organization Science, 2(1), 71-87.

Marsh, S. J., \& Stock, G. N. (2006). Creating dynamic capability: The role of intertemporal integration, knowledge retention, and interpretation. Journal of Product Innovation Management, 23(5), 422-436

Matthyssens, P., Pauweis, P., \& Vandenbempt, K. (2005). Strategic flexibility, rigidity and barriers to the development of absorptive capacity in business markets: Themes and research perspectives. Industrial Marketing Management, 34(6), 547-554.

McEvily, S. K., Eisenhardt, K. M., \& Prescott, J. E. (2004). The global acquisition, leverage, and protection of technological competencies. Strategic Management Journal, 25(8/ 9), 713-722.

McGrath, R. G. (2001). Exploratory learning, innovative capacity, and managerial oversight. Academy of Management Journal, 44(1), 118-131.

Mentzer, J. T., DeWitt, W., Keebler, J. S., Min, S., Nix, N. W., Smith, C. D., et al. (2001) Defining supply chain management. Journal of Business Logistics, 22(2), 1-25.

Molina Morales, F. X., \& Martínez Fernández, M. T. (2010). Social networks: Effects of social capital on firm innovation. Journal of Small Business Management, 48(2), 258-279.

Morgan, N. A., Vorhies, D. W., \& Mason, C. H. (2009). Market orientation, marketing capabilities, and firm performance. Strategic Management Journal, 30(8), 909-920.

Muthén, B., \& Muthén, L. (2010). Mplus user's guide (6th ed.). Los Angeles, CA: Muthén \& Muthén.

Nieto, M. J., \& Santamaria, L. (2010). Technological collaboration: Bridging the innovation gap between small and large firms. Journal of Small Business Management, 48(1), 44-69.

Nonaka, I., \& Takeuchi, H. (1995). The knowledge creating company: How Japanese companies create the dynamics of innovation. New York: Oxford University Press.

Nonaka, I., Toyama, R., \& Hirata, T. (2008). Managing flow: A process theory of the knowledge based firm. New York: Palgrave Macmillan.

O'Connor, G. C. (2008). Major innovation as a dynamic capability: A systems approach. Journal of Product Innovation Management, 25(4), 313-330.

Ortega, M. J. R. (2010). Competitive strategies and firm performance: Technological capabilities' moderating roles. Journal of Business Research, 63(12), 1273-1281.

Paulssen, M., \& Birk, M. M. (2007). Satisfaction and repurchase behavior in a business to business setting: Investigating the moderating effect of manufacturer, company and demographic characteristics. Industrial Marketing Management, 36(7), 983-997.

Payne, A., \& Frow, P. (2005). A strategic framework for customer relationship management. Journal of Marketing, 69(4), 167-176.

Podsakoff, P. M., \& Organ, D. W. (1986). Self reports in organizational research: Problems and prospects. Journal of Management, 12(4), 531-544.

Preacher, K. J., \& Hayes, A. F. (2004). SPSS and SAS procedures for estimating indirect effects in simple mediation models. Behavior Research Methods, Instruments, E Computers, 36(4), 717-731.

Preacher, K. J., \& Hayes, A. F. (2008). Asymptotic and resampling strategies for assessing and comparing indirect effects in multiple mediator models. Behavior Research Methods, 40(3), 879-891.

Reimann, M., Schilke, O., \& Thomas, J. (2010). Customer relationship management and firm performance: The mediating role of business strategy. Journal of the Academy of Marketing Science, 38(3), 326-346.

Reinartz, W., Krafft, M., \& Hoyer, W. D. (2004). The customer relationship management process: Its measurement and impact on performance. Journal of Marketing Research, 41(3), 293-305.

Reinartz, W. J., \& Kumar, V. (2000). On the profitability of long life customers in a noncontractual setting: An empirical investigation and implications for marketing. Journal of Marketing, 64(4), 17-35.

Reinartz, W. J., \& Kumar, V. (2002). The mismanagement of customer loyalty. Harvard Business Review, 80(7), 86-94.

Reinartz, W. J., \& Kumar, V. (2003). The impact of customer relationship characteristics on profitable lifetime duration. Journal of Marketing, 67(1), 77-99.

Rosenkopf, L., \& Nerkar, A. (2001). Beyond local search: Boundary spanning, exploration, and impact in the optical disk industry. Strategic Management Journal 22(4), 287-306.

Rothaermel, F. T., \& Deeds, D. L. (2004). Exploration and exploitation alliances in biotechnology: A system of new product development. Strategic Management Journal, 25(3) 201-221.

Rust, R., Zahorik, A., \& Keiningham, T. L. (1995). Return on quality (ROQ): Making service quality financially accountable. Journal of Marketing, 59(2), 58-71.

Ryals, L. (2005). Making customer relationship management work: The measurement and profitable management of customer relationships. Journal of Marketing, 69(4), 252-261.

Smith, K. G., Collins, C. J., \& Clark, K. D. (2005). Existing knowledge, knowledge creation capability, and the rate of new product introduction in high technology firms. Academy of Management Journal, 48(2), 346-357.

Srinivasan, M., Pauwels, K., Sliva Risso, J., \& Hanssens, D. M. (2009). Product innovations, advertising, and stock returns. Journal of Marketing, 73(1), 24-43.

Stringfellow, A., Nie, W., \& Bowen, D. E. (2004). Profiting from understanding custome needs. Business Horizons, 47(5), 45-52. 
Su, Z., Ahlstrom, D., Li, J., \& Cheng, D. (2013). Knowledge creation capability, absorptive capacity, and product innovativeness. RED Management, 43(5), 473-485.

Sun, P. Y. T., \& Anderson, M. H. (2010). An examination of the relationship between absorptive capacity and organizational learning, and a proposed integration. International Journal of Management Reviews, 12(2), 130-150.

Tajeddini, K., \& Trueman, M. (2008). The potential for innovativeness: A tale of the Swiss watch industry. Journal of Marketing Management, 24(1-2), 169-184.

Teece, D. J., \& Pisano, G. (1994). The dynamic capabilities of firms: An introduction. Industrial and Corporate Change, 3(3), 537-556.

Teece, D. J., Pisano, G., \& Shuen, G. (1997). Dynamic capabilities and strategic management. Strategic Management Journal, 18(7), 509-533.

Theodosiou, M., Kehagias, J., \& Katsikea, E. (2012). Strategic orientations, marketing capabilities and firm performance: An empirical investigation in the context of frontline managers in service organizations. Industrial Marketing Management, 41(7), 1058-1070.

Todorova, G., \& Durisin, B. (2007). Absorptive capacity: Valuing a reconceptualization. Academy of Management Review, 32(3), 774-786.

Tsai, W. (2001). Knowledge transfer in intraorganizational networks: Effects of network position and absorptive capacity on business unit innovation and performance. Academy of Management Journal, 44(5), 996-1004.

Tsai, K. H. (2004). The impact of technological capability on firm performance in Taiwan's electronics industry. The Journal of High Technology Management Research, 15(2), 183-195.

Tsai, K. H., Chou, C., \& Kuo, J. H. (2008). The curvilinear relationships between responsive and proactive market orientation and new product performance: A contingent link. Industrial Marketing Management, 37(8), 884-894.

Tu, Q., Vonderembse, M. A., Ragu Nathan, T. S., \& Sharkey, T. W. (2006). Absorptive capacity: Enhancing the assimilation of time based manufacturing practices. Journal of Operations Management, 24(5), 692-710.

Van den Bosch, F. A. J., Volberda, H. W., \& de Boer, M. (1999). Coevolution of firm absorptive capacity and knowledge environment: Organization forms and combinative capabilities. Organization Science, 10(5), 551-568.

Vega Jurado, J., Gutiérrez Gracia, A., \& Fernández de Lucio, I. (2008). Analyzing the determinants of firm's absorptive capacity: Beyond R\&D. RED Management, 38(4), 392-405.

Verhoef, P. C. (2003). Understanding the effect of customer relationship management ef forts on customer retention and customer share development. Journal of Marketing, 67(4), 30-45
Verona, G. A. (1999). A resource based view of product development. Academy of Management Review, 24(1), 132-142.

Veugelers, R. (1997). Internal R\&D expenditures and external technology sourcing. Research Policy, 26(3), 303-315.

Volberda, H. W., Foss, N. J., \& Lyles, M. A. (2010). PERSPECTIVE-absorbing the concept of absorptive capacity: How to realize its potential in the organization field. Organization Science, 21(4), 931-951.

Vorhies, D. W., \& Morgan, N. A. (2005). Benchmarking marketing capabilities for sustainable competitive advantage. Journal of Marketing, 69(1), 80-94.

Wales, W. J., Parida, V., \& Patel, P. (2013). Too much of a good thing? Absorptive capacity, firm performance, and the moderating role of entrepreneurial orientation. Strategic Management Journal, 34(5), 622-633.

Zahra, S. A., \& George, G. (2002). Absorptive capacity: A review, reconceptualization, and extension. Academy of Management Review, 27(2), 185-203.

Zhou, K. Z., \& Wu, F. (2010). Technological capability, strategic flexibility, and product innovation. Strategic Management Journal, 31(5), 547-561.

Nikolaos Tzokas: Dr. Nikolaos Tzokas is the executive dean of the Faculty of Business at the University of Plymouth UK and Professor in Marketing. His research interests include New Product Development, Knowledge Management, Relationship Marketing and Sales Management.

Young Ah Kim: Dr. Young Ah Kim is a lecturer in Marketing at Essex Business School and is a Certified Purchasing Manager (CPM). Her research interests are in the application of relationship marketing theories to diverse and interdisciplinary problems, in particular, value creation in buyer-supplier relationships.

Hammad Akbar: Dr. Hammad Akbar is a senior lecturer in Management at the University of Liverpool Management School and specializes in organizational knowledge creation.

Haya Al Dajani: Dr Haya Al Dajani is a lecturer in Entrepreneurship and Small Business Management and an associate director for Enterprise, Engagement and External Relations at the Norwich Business School, University of East Anglia, UK. Her research focuses on the critical relationship between empowerment and entrepreneurship and their collective impact on economic and social development. 